\title{
Managing Onion Thrips can Limit Bacterial Stalk and Leaf Necrosis in Michigan Onion Fields
}

\author{
A. S. Grode, ${ }^{1}$ E. Brisco-McCann, ${ }^{2}$ P. Wiriyajitsonboom, ${ }^{3}$ M. K. Hausbeck, ${ }^{2}$ and Z. Szendrei ${ }^{1, \dagger}$ \\ ${ }^{1}$ Department of Entomology, Michigan State University, East Lansing, MI 48824, U.S.A.; ${ }^{2}$ Department of Plant, Soil and \\ Microbial Sciences, Michigan State University, East Lansing, MI 48824, U.S.A.; and ${ }^{3}$ Department of Microbiology, Faculty of \\ Science, Kasetsart University, Bangkok 10900, Thailand
}

\begin{abstract}
Onion thrips (Thrips tabaci) is a major insect pest of onion and it has been identified as a likely vector of Pantoea agglomerans (bacterial stalk and leaf necrosis), a relatively new pathogen to Michigan's onion industry. Our objective was to develop an integrated insect and disease management program by examining the efficacy of bactericides and insecticides alone and in combination to limit bacterial stalk and leaf necrosis caused by $P$. agglomerans. We also examined the association of onion thrips and disease incidence in the field, because thrips are known to transmit this pathogen. In the pesticide trial, insecticides reduced both thrips abundance and bacterial stalk and leaf necrosis incidence whereas bactericides

alone did not reduce disease severity. Positive correlations among thrips population density, numbers of thrips positive for $P$. agglomerans, and bacterial stalk and leaf necrosis incidence in onion fields were determined. This study suggests that onion thrips feeding can facilitate the development of bacterial stalk and leaf necrosis in Michigan's commercial onion fields, and results from the pesticide trials indicate that thrips feeding damage is positively correlated with disease incidence. Therefore, in order to reduce bacterial stalk and leaf necrosis incidence in onion, management efforts should include reducing onion thrips populations through the use of insecticides and other cultural practices.
\end{abstract}

In the United States, the onion industry is valued at $\$ 1$ billion each year (USDA-NASS 2015). Michigan's growers produce over 45 million $\mathrm{kg}$ of pungent onion crops annually, valued at approximately $\$ 10$ million (USDA-NASS 2015). The majority of the onion crop in this state is direct seeded and grown on approximately 1,000 ha (USDA-NASS 2015).

Pathogens of onion, including Botrytis spp. (Lacy and Pontius 1983), Peronospora destructor (Hildebrand and Sutton 1982), Alternaria porri (Everts and Lacy 1990), and Stemphylium spp. (Howard et al. 1994), can cause foliar disease on Michigan onion. In recent years, Stemphylium leaf blight has occurred more commonly than A. porri; P. destructor and Botrytis spp. which occur sporadically (M. Hausbeck, personal communication). Pantoea agglomerans (syn. Erwinia herbicola, causal agent of bacterial stalk and leaf necrosis), has only recently been identified as an onion pathogen in the state, where it was confirmed to cause foliar blight in six counties in 2013 (Tho et al. 2015). In laboratory studies, when the bacterial suspension was directly injected into onion bulbs, rot was observed (Tho et al. 2015).

Disease caused by $P$. agglomerans was first reported in 1981, in an onion seed field in South Africa (Hattingh and Walters 1981); symptoms included stalk and leaf necrosis. In 2006, P. agglomerans was first reported in the United States as a pathogen of onion in Georgia inciting leaf blight and bulb rot (Edens et al. 2006). Symptoms included necrotic streaking with water-soaked margins along the length of the leaf, leading to wilting in severe cases (Dutta et al. 2014). It produces leaf blight symptoms similar to those caused by $P$. ananatis (causal agent of center rot) (Edens et al. 2006). In Michigan, bacterial stalk and leaf necrosis incidence may exceed $80 \%$ in some

${ }^{\dagger}$ Corresponding author: Z. Szendrei; E-mail: szendrei@msu.edu

Funding: Funding for this research was provided by Michigan State University Project GREEEN (award number GR15-057 to Z. Szendrei and M. K. Hausbek) and the Michigan Onion Committee.

The author(s) declare no conflict of interest.

Accepted for publication 8 December 2018.

() 2019 The American Phytopathological Society commercial onion fields (Tho et al. 2015). The long-term impacts of $P$. agglomerans on the onion industry have not yet been measured but its association with other bacteria that incite center rot indicate the potential for economic loss (Dutta et al. 2014).

Onion thrips (Thrips tabaci Lindeman 1889, Thysanoptera: Thripidae) is an important insect pest of onion globally (Lewis 1997) and in Michigan (Quartey 1982). The larvae and adults feed on leaf tissue, removing chlorophyll, thus impairing photosynthesis (Molenaar 1984; Parrella and Lewis 1997), which leads to reduced bulb size and yield (Fournier et al. 1995). The magnitude of yield loss caused by onion thrips feeding is variable but may reach 55\% (Rueda et al. 2007). Insecticides are used for onion thrips management (DiazMontano et al. 2011) and the development of resistance is common among insect populations (Lewis 1997). Growers are advised to rotate insecticide classes and apply them according to established thresholds: 3 thrips/leaf for spinetoram and 1 thrips/leaf for all other insecticides (Byrne and Szendrei 2013; Gill and Garg 2014). Penetrating surfactants are commonly used by Michigan onion growers when making insecticide applications to improve pesticide adherence to leaves but they may also play a direct role in managing thrips populations because they have been found to have detrimental effects on some pests such as the silverleaf whitefly (Sieburth et al. 1998).

In addition to directly feeding on plant tissue, onion thrips play an important role in the transmission of several onion pathogens (Gill et al. 2015). A recent study demonstrated that onion thrips feeding injury promotes colonization of onion leaves by $P$. ananatis (Grode et al. 2017). Based on laboratory experiments, onion thrips can acquire and transmit both $P$. agglomerans and $P$. ananatis (Dutta et al. 2014). In greenhouse transmission studies, $12.5 \%$ of onion thrips acquired $P$. agglomerans after $1 \mathrm{~h}$ of feeding on inoculated onion, and $48 \mathrm{~h}$ of feeding resulted in $92 \%$ acquisition (Dutta et al. 2014). Disease symptoms were also observed on $70 \%$ of onion seedlings after 12 days of feeding by $P$. agglomerans-infected thrips (Dutta et al. 2014).

For several years beginning in 2013, onion growers in Michigan observed a high incidence of bacterial stalk and leaf necrosis in their fields, leading to premature leaf senescence. Preliminary studies indicated that copper did not consistently limit this bacterial disease (Wiriyajitsomboon et al. 2014). The objective of our study was to evaluate an integrated insect and disease management program by using bactericides and insecticides alone and in combination to reduce bacterial stalk and leaf necrosis disease severity. The association 
between onion thrips and disease incidence in the field was also of interest given that thrips transmit this pathogen (Dutta et al. 2014).

\section{Materials and Methods}

Bactericide and insecticide trial. Experimental design. To assess the effectiveness of different bactericides applied alone or in combination with an insecticide, a field trial was conducted during the 2015 and 2016 growing seasons. Sedona onion crops were direct seeded on 29 April 2015 and 16 April 2016 in a commercial field in Stockbridge, MI. The field was managed by the grower cooperator following commercial standard practices, including overhead irrigating, fertilizing, and spraying fungicides. Fungicides recommended to prevent foliar fungal diseases and downy mildew were applied at regular intervals. The commercial fungicide program consisted of chlorothalonil, mancozeb, and azoxystrobin applied in alternation at 7- to 10day intervals using a tractor-mounted boom delivering $187 \mathrm{ha}^{-1}$ at $276 \mathrm{kPa}$. Weeds were managed using pre- and postemergent herbicides. No insecticides were applied across the field by the grower cooperator. The trial was arranged in a randomized complete block design, with 13 treatments replicated across four blocks. Each plot was three rows wide $(30 \mathrm{~cm}$ between rows) and $6 \mathrm{~m}$ long, with a $60-\mathrm{cm}$ buffer zone in between each plot, containing approximately 360 plants/plot spaced $5 \mathrm{~cm}$ apart. Three bactericides were tested: two copper hydroxide products (Kocide 3000; DuPont, Wilmington, DE, U.S.A. and Nu-Cop 50; Albough Inc., Ankeny, IA, U.S.A.) and an antibiotic (Kasugamycin; Hokko Chemical Industry Co. Ltd, Tokyo, Japan) (Table 1). A grower standard insecticide program was tested alone or in combination with the bactericides and a nonionic surfactant (Dyne-Amic; Helena Chemical Company, Collierville, TN, U.S.A.) (Table 1). In 2015, the insecticide program consisted of two applications of spinetoram (Radiant SC; Dow AgroSciences, Indianapolis, IN, U.S.A.) followed by two applications of abamectin (Agri-Mek SC; Syngenta, Basel, Switzerland) at weekly intervals. In 2016, the insecticide program consisted of weekly sprays of the following: two applications of spirotetramat (Movento; Bayer CropScience LP, Research Triangle Park, NC, U.S.A.), followed by two applications of spinetoram, then two applications of abamectin, then one application of methomyl (Lannate LV; DuPont). A penetrating surfactant (Dyne-Amic) was added at $0.05 \%$ ( $\mathrm{vol} / \mathrm{vol})$ in some treatments (Table 1$)$. These treatments were compared with an untreated control that was not sprayed with insecticides or bactericides. Additional controls included the insecticide program alone, the insecticide program plus the surfactant, and the surfactant alone. The bactericide program was initiated on 28 May 2015 and 22 June 2016, when plants had three to five leaves. The insecticide program was initiated once the action threshold of 1 thrips/ leaf was reached (Nault and Shelton 2010) on 22 July 2015 and 29 June 2016. Initiation of the insecticide program was considerably later in 2015 than in 2016 due to abnormally wet early-season conditions that delayed an increase in the thrips population. All combination treatments were tank mixed before application. All products were applied using a $\mathrm{CO}_{2}$ backpack sprayer and a broadcast boom equipped with three XR8003 flat-fan nozzles (TeeJet Technologies, Wheaton, IL, U.S.A.), with the outer nozzles angled toward the center of the plot, calibrated at $345 \mathrm{kPa}$, and delivering 467 liters $\mathrm{ha}^{-1}$.

Sampling protocol. Prior to initiating insecticide applications, 50 plants randomly selected from across the trial were scouted weekly. Thrips were counted on the entire aboveground parts of plants to calculate the number of thrips per leaf and determine when the action threshold of 1 thrips/leaf was reached to initiate the insecticide spray program. After the insecticide program began, the average number of thrips per leaf was calculated each week by counting the number of thrips on 10 randomly selected plants in each plot, and the total number of leaves per plant on 20 randomly selected plants in the field. These counts occurred weekly from 22 July to 24 August 2015 and from 29 June to 17 August 2016.

Leaf blight severity was visually evaluated as the average percentage of leaf tissue with bacterial stalk and leaf necrosis symptoms per plant per plot on a 0 -to- $100 \%$ scale. P. agglomerans produces necrotic streaking, with water-soaked margins along the length of the leaf (Tho et al. 2015). Fungal foliar diseases can be readily discernable from bacterial leaf necrosis by visual assessments (Schroeder et al. 2013; Tho 2018). For example, downy mildew results in sporulation that occurs on the green tissue that borders the recently invaded necrotic tissue. Botrytis spp. infection is discernable from bacterial diseases because it results in characteristic white flecks that are small. Stemphylium spp. infection produces light-brown to purple individual lesions that elongate and coalesce into extended leaf areas, resulting in blighting with the sporulating pathogen evident. Plants were evaluated 1 week following the final pesticide application, on 24 August 2015 and 17 August 2016.

Statistical analysis. The seasonal mean number of thrips per plant was $\log (x+0.1)$ transformed and compared among the 13 treatments

Table 1. Seasonal average number of thrips per leaf and bacterial stalk and leaf necrosis incidence in 2015 and 2016 when treated with a bactericide or an insecticide program

\begin{tabular}{|c|c|c|c|c|c|c|c|}
\hline \multirow[b]{2}{*}{ Product } & \multirow[b]{2}{*}{ Ingredient $^{\mathbf{v}}$} & \multirow[b]{2}{*}{ Progw } & \multirow[b]{2}{*}{ Surf $\mathrm{f}^{\mathrm{x}}$} & \multicolumn{2}{|c|}{$2015^{u}$} & \multicolumn{2}{|c|}{$2016^{u}$} \\
\hline & & & & Disease $^{y}$ & Thrips $^{\mathbf{z}}$ & Disease $^{y}$ & Thrips $^{\mathbf{z}}$ \\
\hline$\ldots$ & $\ldots$ & - & - & $72.6 \pm 11.9 \mathrm{ab}$ & $3.7 \pm 0.27 \mathrm{a}$ & $50.0 \pm 7.2 \mathrm{a}$ & $8.2 \pm 0.47 b$ \\
\hline Kocide 3000 & $\mathrm{Cu}(\mathrm{OH})_{2}$ & - & - & $72.6 \pm 11.9 \mathrm{ab}$ & $3.8 \pm 0.27 \mathrm{a}$ & $37.5 \pm 0.0 \mathrm{~b}$ & $11.5 \pm 0.75 \mathrm{a}$ \\
\hline Kasugamycin & Kasugamycin & - & - & $81.3 \pm 0.0 \mathrm{a}$ & $3.0 \pm 0.21 \mathrm{a}$ & $56.3 \pm 6.3 \mathrm{a}$ & $9.9 \pm 0.63 \mathrm{ab}$ \\
\hline NuCop 50 & $\mathrm{Cu}(\mathrm{OH})_{2}$ & - & - & $90.2 \pm 3.5 \mathrm{a}$ & $3.3 \pm 0.26 \mathrm{a}$ & $50.0 \pm 7.2 \mathrm{a}$ & $10.4 \pm 0.82 \mathrm{a}$ \\
\hline Kocide 3000 & $\mathrm{Cu}(\mathrm{OH})_{2}$ & + & - & $32.8 \pm 4.8 \mathrm{c}$ & $1.3 \pm 0.13 \mathrm{bcd}$ & $7.9 \pm 1.1 \mathrm{c}$ & $4.8 \pm 0.32 \mathrm{c}$ \\
\hline Kasugamycin & Kasugamycin & + & - & $52.3 \pm 15.6 \mathrm{bc}$ & $0.8 \pm 0.08 \mathrm{~d}$ & $7.9 \pm 1.1 \mathrm{c}$ & $4.2 \pm 0.31 \mathrm{c}$ \\
\hline NuCop 50 & $\mathrm{Cu}(\mathrm{OH})_{2}$ & + & - & $39.0 \pm 9.0 \mathrm{c}$ & $1.4 \pm 0.12 b$ & $16.1 \pm 2.4 \mathrm{c}$ & $4.5 \pm 0.32 c$ \\
\hline Kocide 3000 & $\mathrm{Cu}(\mathrm{OH})_{2}$ & + & + & $34.3 \pm 10.4 \mathrm{c}$ & $1.4 \pm 0.13 b$ & $13.8 \pm 2.7 \mathrm{c}$ & $3.9 \pm 0.25 \mathrm{c}$ \\
\hline Kasugamycin & Kasugamycin & + & + & $45.3 \pm 10.7 \mathrm{c}$ & $0.9 \pm 0.12 \mathrm{~cd}$ & $9.0 \pm 0.0 \mathrm{c}$ & $3.2 \pm 0.24 \mathrm{c}$ \\
\hline NuCop 50 & $\mathrm{Cu}(\mathrm{OH})_{2}$ & + & + & $43.8 \pm 6.3 \mathrm{c}$ & $1.4 \pm 0.12 \mathrm{bc}$ & $13.8 \pm 2.7 \mathrm{c}$ & $3.7 \pm 0.24 \mathrm{c}$ \\
\hline$\ldots$ & $\ldots$ & + & - & $45.3 \pm 10.7 \mathrm{c}$ & $1.2 \pm 0.13 \mathrm{bcd}$ & $11.4 \pm 2.4 \mathrm{c}$ & $3.7 \pm 0.29 \mathrm{c}$ \\
\hline$\ldots$ & $\ldots$ & + & + & $34.3 \pm 10.3 \mathrm{c}$ & $1.0 \pm 0.10 \mathrm{bcd}$ & $9.0 \pm 0.0 \mathrm{c}$ & $3.7 \pm 0.27 \mathrm{c}$ \\
\hline$\ldots$ & $\ldots$ & - & + & $84.8 \pm 3.6 \mathrm{a}$ & $3.1 \pm 0.21 \mathrm{a}$ & $50.0 \pm 7.2 \mathrm{a}$ & $10.2 \pm 0.61 \mathrm{a}$ \\
\hline
\end{tabular}

u Different letters indicate differences among treatments, Tukey's honestly significant difference, $\alpha<0.05$.

$\checkmark$ Active ingredient. All treatments that contain copper hydroxide $\left(\mathrm{Cu}(\mathrm{OH})_{2}\right)$ were applied at $1.68 \mathrm{~kg} \mathrm{ha}^{-1}$ and all treatments that contain Kasugamycin were applied at 2.34 liters ha ${ }^{-1}$.

w Insecticide program, yes (+) or no (-).

${ }^{x}$ Surfactant, yes (+) or no (-). Nonionic surfactant (Dyne-Amic) was added at $0.05 \%$ (vol/ $\mathrm{vol}$ ).

y Diseased leaf tissue \pm standard error (SE) was measured at the end of the season as the percentage of leaf tissue showing bacterial stalk and leaf necrosis symptoms per plot.

$\mathrm{z}$ The seasonal average number of thrips per leaf \pm SE was calculated by averaging the sum of thrips per leaf and dividing by the average number of leaves per plant. 
using an analysis of variance (ANOVA) where treatment was the fixed factor and block by date interaction was the random factor. Mean necrotic leaf tissue was also compared among the 13 treatments using an ANOVA where treatment was the fixed factor and block was the random factor. Tukey's honestly significant difference (HSD) tests were used to determine differences among treatment means using the 'HSD.test' function in the 'agricolae' package (Mendiburu 2016). To determine differences between treatments receiving insecticide and treatments without insecticide, $t$ tests were conducted using the 'glht' function in the 'multcomp' package (Hothorn et al. 2008). All statistical analyses were conducted using R software (R Core Team 2015).

Onion thrips and bacterial stalk and leaf necrosis field surveys. Field plots and sampling protocol. Two muck soil fields (3.0 to 4.5 ha) from each of four Michigan commercial onion farms located in Newaygo, Allegan, Ingham, and Clinton counties were selected; 10 sampling plots $\left(7.62 \mathrm{~m}^{2}\right.$ each) were established per field for a total of 80 plots/year. Fields were planted, fertilized, and irrigated (overhead) by the cooperating grower according to standard practices. Fungal foliar diseases were managed using commercial standard fungicide programs; insecticides were not applied. Onion foliage was sampled for thrips and bacterial stalk and leaf necrosis symptoms weekly between 15 June and 10 August 2015 (9 sampling dates) and 6 June and 8 August 2016 (10 sampling dates). Plants were between the two- and four-leaf stage when sampling began; 5 plants were randomly collected from each of the 10 plots for a total of 400 onion plants collected per week across all fields. Individual plants were removed from the soil, placed singly in plastic bags in order to retain all thrips, and placed into coolers for transport to the laboratory.

Laboratory analysis. Each sample was assessed for thrips by counting the total number of adults and juveniles. In all, 1 to 15 thrips (mixture of adults and larvae) per plant were collected to screen for $P$. agglomerans. Insects selected for DNA extraction were frozen in 90\% ethanol. Whole thrips DNA extractions were performed using the DNeasy blood and tissue kit (Qiagen, Hildon, Germany). The protocol was modified by using $25 \%$ of all extraction buffers to optimize the concentration of DNA $(25.0 \pm 3.0 \mathrm{ng} / \mu \mathrm{l})$ in samples containing 1 to 15 thrips that were eluted with $50 \mu$ l of buffer. Extracted DNA was screened for the presence of $P$. agglomerans using quantitative polymerase chain reaction (qPCR) with the species-specific pagRrt2 primer set and pagR2 probe (Braun-Kiewnick et al. 2012). qPCRs were performed in final reaction volumes of $10 \mu$ l containing $5 \mu l$ of $2 \times$ TaqMan master mix (Life Technologies, Grand Island NY, U.S.A.), $0.4 \mu \mathrm{l}$ of double-distilled $\mathrm{H}_{2} \mathrm{O}, 900 \mathrm{nM}$ pagRrt2 forward and reverse primers, $200 \mathrm{nM}$ pagR2 TaqMan probe, and $2 \mu \mathrm{l}$ of insect DNA. PCRs were performed on a StepOnePlus Real-Time PCR System (Applied Biosystems, Foster City, CA, U.S.A.). Reactions were held at $50^{\circ} \mathrm{C}$ for $2 \mathrm{~min}$ and $95^{\circ} \mathrm{C}$ for $10 \mathrm{~min}$, followed by $45 \mathrm{cy}-$ cles of $95^{\circ} \mathrm{C}$ for $15 \mathrm{~s}$ and $60^{\circ} \mathrm{C}$ for $2 \mathrm{~min}$. All PCR were run with a negative control consisting of the PCR mix and $2 \mu \mathrm{l}$ of doubledistilled $\mathrm{H}_{2} \mathrm{O}$ as well as a dilution series consisting of purified bacterial plasmids $\left(10^{5}\right.$ to 1 copy/ $\left./ \mu \mathrm{l}\right)$. All PCR were conducted as duplicates of each sample. Any sample with an average cycle threshold value $<40$ was considered positive (Braun-Kiewnick et al. 2012).

Following thrips assessment, the plants were visually assessed for bacterial stalk and leaf necrosis symptoms, including leaf lesions with water-soaked tissue that expand along the length of the leaf toward the bulb, as described by Schroeder et al. (2013). From these plants, a subset of symptomatic plants was randomly selected for bacterial isolation and identification. Plants were rinsed with running tap water and the foliage was allowed to dry for approximately $1 \mathrm{~h}$. Leaf tissue from the margin of the water-soaked tissue was excised ( 1.0 by $1.0 \mathrm{~cm}^{2}$ ) using a sterile scalpel blade, dipped briefly in $95 \%$ ethanol, rinsed with sterile distilled water twice, dried for $3 \mathrm{~min}$, and placed on a clean microscope slide. The disinfected leaf piece was cut in half using a sterile scalpel blade. A 50- $\mu$ l drop of sterile distilled water was pipetted onto the cut area where bacterial cells were released from the tissue into the water. The suspension was streaked onto nutrient broth yeast extract (NBY) agar using a sterile bacterial loop, and incubated at $30^{\circ} \mathrm{C}$ for 2 to 7 days. Each bacterial colony that had different morphological characteristics (form and color) was selected and transferred to fresh NBY agar twice, resulting in pure cultures for identification. In 2015, 307 isolations were conducted and 202 colonies were continued to pure cultures based on similarity to $P$. agglomerans colony morphology, as described by Tho et al. (2015). In 2016, 225 isolations were conducted and 179 colonies were continued to pure cultures based on similarity to $P$. agglomerans colony morphology. In order to assess the accuracy of morphological identification, representative colonies (66 isolates in 2015 and 9 isolates in 2016) were initially identified using the BIOLOG GN Microtiter Plates (BIOLOG Inc., Hayward, CA, U.S.A.) according to the manufacturer's instructions.

In 2015 , to confirm the identities of the bacteria, 178 individual isolates from the pure cultures described above were sequenced using the small subunit of the bacterial ribosomal DNA (16S rDNA) gene. DNA extraction was performed according to the protocol of the Wizard Genomic DNA Purification kit (Promega Corp., Leiden, The Netherlands). DNA quantity was measured using a Nanodrop 1000 spectrophotometer (Thermo Scientific, Wilmington, DE, U.S.A.). The 16S rDNA was amplified with a previously developed $16 \mathrm{~S}$ primer set (amplicon size $=1,491 \mathrm{bp}$ ) (De Baere et al. 2004). A total volume of $25 \mu \mathrm{l}$ of PCR mixture contained $1 \times$ PCR buffer, $0.2 \mu \mathrm{M}$ dNTPs, $0.2 \mu \mathrm{M}$ each primer, and $0.625 \mathrm{U}$ of Taq polymerase (Promega Corp., Madison, WI, U.S.A.). The PCR were conducted in a Mastercycler Pro thermocycler (Eppendorf, Hauppauge, NY, U.S.A.) with an initial denaturation at $94^{\circ} \mathrm{C}$ for $5 \mathrm{~min}$; followed by 3 cycles of denaturation at $94^{\circ} \mathrm{C}$ for $45 \mathrm{~s}$, annealing at $52^{\circ} \mathrm{C}$ for $2 \mathrm{~min}$, and extension at $72^{\circ} \mathrm{C}$ for $1 \mathrm{~min}$; and another 30 cycles of denaturation at $94^{\circ} \mathrm{C}$ for $20 \mathrm{~s}$, annealing at $52^{\circ} \mathrm{C}$ for $1 \mathrm{~min}$, and extension at $72^{\circ} \mathrm{C}$ for $1 \mathrm{~min}$. The final extension step was performed at $72^{\circ} \mathrm{C}$ for $7 \mathrm{~min}$. The PCR products were visualized on $1.5 \%$ agarose gel, dissolved in $1 \times$ Tris-borate-EDTA buffer. One of each PCR product was sequenced with a single primer by submitting to Macrogen Corp. (Macrogen USA, Rockville, MD, U.S.A.). The nucleotide sequences were compared with the nucleotide collection in the National Center for Biotechnology Information (NCBI) using a BLASTn search (https://blast.ncbi.nlm.nih. gov/Blast.cgi) analysis. Bacterial isolates were not sequenced in 2016.

Statistical analysis. Pearson product-moment correlation coefficients were computed to assess the relationships among mean thrips per plant, proportion of thrips positive for P. agglomerans, and proportion of plants with bacterial stalk and leaf necrosis symptoms. Differences among fields and dates for each dependent variable were compared using an ANOVA followed by Tukey's HSD.

\section{Results}

Bactericide and insecticide trial. In both growing seasons, all treatments that included an insecticide had significantly fewer thrips than treatments without insecticide (2015: $F=57.5, d f=12,24, P<$ 0.01; 2016: $F=71.4, d f=12,24, P<0.01$ ) (Table 1). In 2015 only, the treatments containing Kasugamycin and insecticide provided better control of thrips than the insecticide treatments containing the other two bactericides (Kocide and NuCop). The number of thrips among treatments containing bactericides mixed with insecticide compared with insecticide alone did not differ in 2015 and 2016. Adding a surfactant did not significantly impact thrips control or leaf blight severity (Table 1).

There was a significant treatment effect on bacterial stalk and leaf necrosis severity in both growing seasons (2015: $F=7.82, d f=12$, 36, $P<0.01 ; 2016: F=22.9, d f=12,36, P<0.01$ ) (Table 1). In both years, all treatments that included the insecticide program had significantly reduced bacterial stalk and leaf necrosis disease severity compared with the treatments without insecticide. Treatments that included insecticide averaged 39.5 and $37.7 \%$ less diseased leaf tissue than treatments without insecticide in 2015 and 2016, respectively $(P<0.01)$. Bacterial stalk and leaf necrosis severity was similar among the eight treatments that contained an insecticide in 
both years (Table 1). Fungal foliar diseases within the trial were prevented by the fungicide program and were not visually detected.

Onion thrips and bacterial stalk and leaf necrosis field surveys. The total number of thrips samples that tested positive for P. agglomerans was $35.6 \%$ (450 of 1,264) in 2015 and $14 \%$ (276 of 1,977) in 2016. Percentage of thrips that tested positive for $P$. agglomerans (2015: $F=1.7, d f=7,56, P=0.12 ; 2016: F=1.8, d f=7,61, P>$ 0.09 ) and percentage of plants with bacterial stalk and leaf necrosis symptoms $(2015: F=1.7, d f=7,56, P=0.13 ; 2016: F=2.1, d f=$ $7,61, P=0.06$ ) did not significantly differ among fields. The number of thrips per plant, percentage of thrips that tested positive for $P$. agglomerans, and percentage of plants with bacterial stalk and leaf necrosis symptoms increased over the course of each growing season. The mean number of thrips per plant significantly differed among sampling dates (2015: $F=35.9, d f=8,62, P<0.01 ; 2016$ : $F=2.6, d f=9,61, P<0.01)$, reaching about 4 thrips/plant by the end of the growing season. Percentage of thrips positive for $P$. agglomerans also differed among sampling dates (2015: $F=9.7$, $d f=8,62, P<0.01 ; 2016: F=4.3, d f=9,61, P<0.05$ ) (Fig. 1 ). Percentage of plants with bacterial stalk and leaf necrosis significantly differed among sampling dates (2015: $F=31.8, d f=8,62, P<$ $0.01 ; 2016: F=16.0, d f=9,61, P<0.01)$, reaching $100 \%$ by the end of the growing season (Fig. 1). Fungal foliar diseases were not detected because they were well managed by commercial fungicide programs.

There was a significant positive correlation between percentage of plants with bacterial stalk and leaf necrosis symptoms and the mean number of thrips per plant in both growing seasons (2015: $R^{2}=0.26, P<0.05 ; 2016: R^{2}=0.30, P<0.01$ ) (Fig. $2 \mathrm{~A}$ and $\mathrm{B}$ ). There was a significant positive correlation between percentage of plants with bacterial stalk and leaf necrosis symptoms and percentage of thrips that screened positive for $P$. agglomerans in both growing seasons (2015: $\left.R^{2}=0.59, P<0.01 ; 2016: R^{2}=0.23, P<0.05\right)$ (Fig. $2 \mathrm{C}$ and D).

Of the bacterial isolates that were isolated from onion plants and identified using BIOLOG, 26\% (17 of 66) and 89\% (8 of 9) were identified as $P$. agglomerans in 2015 and 2016, respectively. Of the isolates that were sequenced for identity confirmation in 2015 , $39 \%$ (70 of 178) were identified as P. agglomerans (97 to $99 \%$ identity compared with the NCBI database using BLASTn) and 15\% (27 of 178) were identified as $P$. ananatis. An additional 21 isolates (12\%) were identified as Pantoea spp. Complete results included $\mathrm{Ba}$ cillus spp. (4\%), Curtobacterium sp. (1\%), Enterobacter spp. (2\%), Enterobacteriaceae sp. (1\%), Erwinia sp. (1\%), Leucobacter sp. (1\%), Microbacterium spp. (3\%), Micrococcus sp. (1\%), Plantibacter sp. (1\%), Pseudomonas spp. (10\%), and Stenotrophomonas spp. (8\%). The remaining $2 \%$ were unidentified or had no results. Sequencing of isolates was conducted in 2015 to confirm symptom identification and was considered sufficient, such that isolate sequencing was not conducted in 2016.

\section{Discussion}

Bacterial stalk and leaf necrosis has been observed frequently in many Michigan onion fields since 2013 and effective disease management strategies are needed. Results from this study indicated that limiting onion thrips with insecticides can also reduce bacterial stalk and leaf necrosis disease severity. This finding is important for onion growers in Michigan and reveals that thrips are likely contributing to the spread of the pathogen because disease severity increased with an increase in thrips abundance.

Kasugamycin has potential to limit bacterial pathogens and was found effective in controlling of E. amylovora (McGhee and Sundin 2011) and Pseudomonas savastanoi pv. savastanoi (Nguyen et al. 2018), the causal agents of fire blight and olive knot, respectively. However, in our study, in the absence of insecticides, kasugamycin treatments resulted in similar levels of disease as the control. Kasugamycin is not currently registered for use on onion in the United States and our results indicate that it is unlikely to provide protection against bacterial stalk and leaf necrosis. The other bactericides evaluated in our study, Kocide 3000 and NuCop 50, also did not provide a significant level of control when applied alone, with the exception of Kocide 3000 in 2016.

In each year of this study, bacterial stalk and leaf necrosis symptoms were observed approximately 3 weeks before thrips populations began to increase. Thrips populations began to increase in late July during both growing seasons and coincided with greater than $90 \%$ incidence of foliar disease symptoms across all fields. Thrips that were positive for Pantoea agglomerans peaked at approximately $20 \%$ by the end of the sampling period, close to the time of crop harvest. Insecticide applications are often decreased near harvest time, leading to an increase in thrips populations and coinciding with exodus flights of thrips from the field (Smith et al. 2015). The role of overwintering thrips in introducing the bacteria to subsequent onion crops is unknown; however, because $6 \%$ of our thrips samples were positive for $P$. agglomerans in the first samples (two- to four-leaf stage) for both years, this may be a potential mechanism for the pathogen to survive and spread and warrants further research. Because $P$. agglomerans is ubiquitous in the environment and not all strains are pathogenic, future studies should include pathogenicity assessments for thrips that are positive for P. agglomerans.

Although our field data cannot prove that onion thrips vector the bacterium, the field surveys together with data from the pesticide trial support the idea of thrips as vectors of $P$. agglomerans; insecticide treatments significantly reduced disease symptoms on leaves. Although stercorarian mode of transmission has been verified (Dutta et al. 2014), it is possible that, under field conditions, thrips also carry bacteria on their integument. Furthermore, thrips feeding has been shown to provide entrance points for $P$. ananatis inoculum (Grode et al. 2017). A similar relationship has been documented between onion thrips and the fungal pathogen A. porri, causal agent of purple blotch (McKenzie et al. 1993). When thrips injury was present, $A$. porri was able to penetrate through areas damaged by onion thrips. However, $P$. agglomerans may also be carried to the plants by wind and splashing water (Schroeder et al. 2013), then use thrips feeding injury as entry points into the plant.

Our pathogen sequencing revealed a relatively low success rate in recovering the two Pantoea spp. from symptomatic field samples, which may indicate a need for improvement in isolation technique. It is important to prevent both $P$. agglomerans and

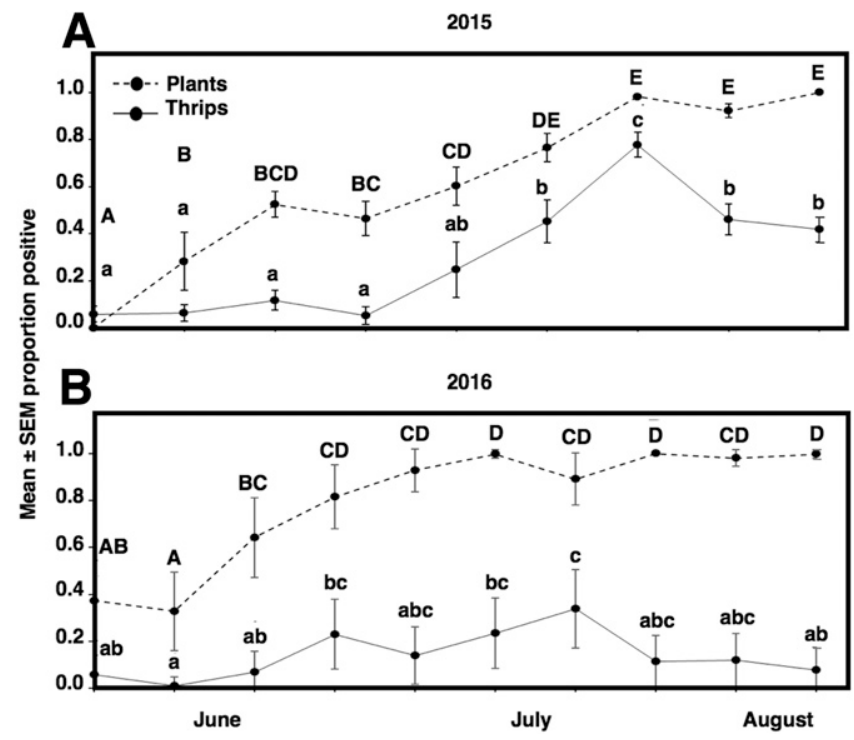

Fig. 1. Mean ( \pm standard error of the mean [SEM]) proportion of thrips that screened positive for Pantoea agglomerans using quantitative polymerase chain reaction and mean $( \pm$ SEM) proportion of plants with bacterial stalk and leaf necrosis symptoms at each sampling period during the A, 2015 and B, 2016 growing seasons. Each point represents the average across eight fields. Uppercase letters represent mean differences in plants with bacterial stalk and leaf necrosis symptoms and lowercase letters represent mean differences in thrips positive for $P$. agglomerans. Points with the same letter are not statistically significant from each other. 
$P$. ananatis from progressing into the bulb late in the growing season because bulb rot can occur during long-term storage (Edens et al. 2006; Vahling-Armstrong et al. 2016); however, there is no current documented evidence that increased levels of stalk and leaf necrosis has led to increased levels of center rot in Michigan. Laboratory studies have demonstrated bulb infection when the bulb is inoculated with $P$. ananatis or $P$. agglomerans directly (Tho et al. 2015; Vahling-Armstrong et al. 2016) but this may or may not be similar to what occurs under field conditions. Currently, $P$. ananatis is not as prevalent as $P$. agglomerans in Michigan's commercial onion industry (M. Hausbeck, personal communication) but the similar acquisition rates and modes of vectoring of the two bacteria indicate that onion thrips are able to spread both pathogens in a similar way (Dutta et al. 2014, 2016). Leach et al. (2017) demonstrated that protecting onion crops from thrips damage using insecticides can increase yields by 10 to $54 \%$. From the results of the current studies, we hypothesize that this is not only due to the reduction in damage from thrips feeding but also may be a result of reduced stalk and leaf necrosis because there are fewer thrips present to potentially disseminate the pathogen. DNA analysis of our isolates resulted in lower than expected percentages of $P$. agglomerans and $P$. ananatis. Some of the isolates that were identified may be responsible for the disease symptoms seen in the field samples although, with the exception of Bacillus sp., Enterobacter sp., Microbacterium sp., Pseudomonas sp., and Stenotrophomonas sp., only single individual isolates were obtained, and these isolates are not likely to be contributing to disease.
Understanding the population threshold that must be exceeded for disease development could be useful in order to time insecticide applications for thrips control to minimize pathogen transmission and spread. Susceptibility to $P$. agglomerans at different onion plant ages could also be a future avenue for research because if certain stages are more or less susceptible, this can have ramifications for management strategies and, specifically, for pesticide application timing. Stumpf et al. (2017) found that onion plants were significantly more susceptible to $P$. ananatis infection during the first leaf senescence stage than during bulb initiation or bulb swelling, suggesting that management strategies that focus on protecting more susceptible stages could be more efficacious. This phenomenon has also been found in other onion systems: in the case of purple blotch (A. porri), onion leaves are more susceptible to infection as they age and emerging leaves are more susceptible later in the season, closer to bulb maturity (Miller 1983).

The inoculum source for $P$. agglomerans is currently unknown but it has been speculated to be seedborne (Walcott et al. 2002) and has been identified from other crops such as rice (Feng et al. 2006). Onion thrips are known to feed and overwinter on a variety of weed species (Smith et al. 2011) before colonizing volunteer onion in the field the following spring (Larentzaki et al. 2007). If onion thrips are interacting with $P$. agglomerans on other host plants before the start of the growing season, they may be introducing it into the onion field. Screening volunteer onion plants and weeds early in the growing season for bacterial stalk and leaf necrosis symptoms as well as thrips carrying $P$. agglomerans could provide important insight as to how
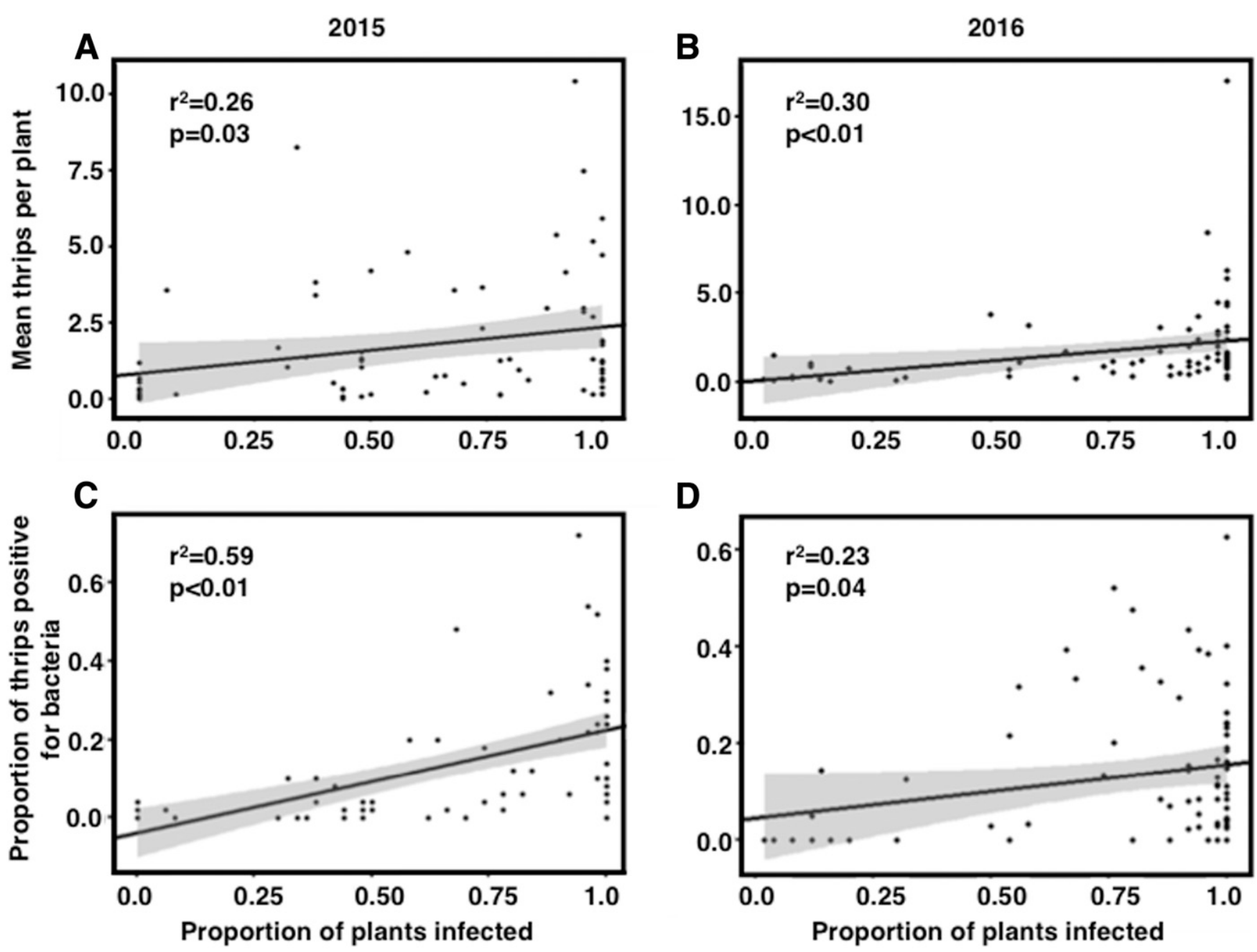

Fig. 2. Proportion of plants with bacterial stalk and leaf necrosis symptoms correlated with the mean ( \pm standard error of the mean) thrips per plant in $\mathbf{A}, 2015$ and $\mathbf{B}, 2016$. The proportion of plants with bacterial stalk and leaf necrosis symptoms correlated with the proportion of thrips that screened positive for Pantoea agglomerans in C, 2015 and D, 2016. Each point represents one field for each date. Shaded gray areas indicate $95 \%$ confidence interval of the mean. 
the pathogen is being introduced into onion fields. Future research should focus on revising action thresholds to optimize onion thrips management because thrips carrying bacteria may lower the current thresholds, and this may lead to optimized bacterial stalk and leaf necrosis management.

\section{Acknowledgments}

We thank all the cooperating onion growers who allowed us access to their farm for onion sampling and conducting the pesticide trial; and D. VanderZee, C. Mccalmon, L. Komondy, G. Nagle, and A. Thiemkey for assistance in processing the samples.

\section{Literature Cited}

Braun-Kiewnick, A., Lehmann, A., Rezzonico, F., Wend, C., Smits, T. H., and Duffy, B. 2012. Development of species-, strain-and antibiotic biosynthesisspecific quantitative PCR assays for Pantoea agglomerans as tools for biocontrol monitoring. J. Microbiol. Methods 90:315-320.

Byrne, A. M., and Szendrei, Z. 2013. Onion thrips control. Arthropod Manage. Tests. 38:E34.

De Baere, T., Verhelst, R., Labit, C., Verschraegen, G., Wauters, G., Claeys, G., and Vaneechoutte, M. 2004. Bacterium infection with Pantoea ananatis. J. Clin. Microbiol. 42:4393-4395.

Diaz-Montano, J., Fuchs, M., Nault, B. A., Fail, J., and Shelton, A. M. 2011. Onion thrips (Thysanoptera: Thripidae): A global pest of increasing concern in onion. J. Econ. Entomol. 104:1-13.

Dutta, B., Barman, A. K., Srinivasan, R., Avci, U., Ullman, D. E., Langston, D. B., and Gitaitis, R. D. 2014. Transmission of Pantoea ananatis and P. agglomerans, causal agents of center rot of onion (Allium cepa), by onion thrips (Thrips tabaci) through feces. Phytopathology 104:812-819.

Dutta, B., Gitaitis, R., Barman, A. K., Avci, U., Marsigan, K., and Srinivasan, R. 2016. Interactions between Frankliniella fusca and Pantoea ananatis in the center rot epidemic of onion (Allium cepa). Phytopathology 106:956-962.

Edens, D. G., Gitaitis, R. D., Sanders, F. H., and Nischwitz, C. 2006. First report of Pantoea agglomerans causing a leaf blight and bulb rot of onions in Georgia. Plant Dis. 90:1551.

Everts, K. L., and Lacy, M. L. 1990. Influence of environment on conidial concentration of Alternaria porri in air and on purple blotch incidence on onion. Phytopathology 80:1387-1391.

Feng, Y., Shen, D., and Song, W. 2006. Rice endophyte Pantoea agglomerans YS19 promotes host plant growth and affects allocations of host photosynthates. J. Appl. Microbiol. 100:938-945.

Fournier, F., Boivin, G., and Stewart, R. K. 1995. Effect of Thrips tabaci (Thysanoptera: Thripidae) on yellow onion yields and economic thresholds for its management. J. Econ. Entomol. 88:1401-1407.

Gill, H. K., and Garg, H. 2014. Pesticide: Environmental impacts and management strategies. Pages 187-230 in: Pesticides-Toxic Effects. S. Solenski and M. L. Larramenday, eds. Intech, Rijeka, Croatia. https://www.intechopen.com/books/ pesticides-toxic-aspects/pesticides-environmental-impacts-and-managementstrategies

Gill, H. K., Garg, H., Gill, A. K., Gillett-Kaufman, J. L., and Nault, B. A. 2015. Onion thrips (Thysanoptera: Thripidae) biology, ecology, and management in onion production systems. J. Integr. Pest Manage. 6:6.

Grode, A., Chen, S., Walker, E. D., and Szendrei, Z. 2017. Onion thrips (Thysanoptera: Thripidae) feeding promotes infection by Pantoea ananatis in onion. J. Econ. Entomol. 110:2301-2307.

Hattingh, M. J., and Walters, D. F. 1981. Stalk and leaf necrosis of onion caused by Erwinia herbicola. Plant Dis. 65:615-618.

Hildebrand, P. D., and Sutton, J. C. 1982. Weather variables in relation to an epidemic of onion downy mildew. Phytopathology 72:219-224.

Hothorn, T., Bretz, F., and Westfall, P. 2008. Simultaneous inference in general parametric models. Biom. J. 30:346-363.

Howard, R. J., Garland, J. A., and Seaman, W. L., eds. 1994. Onion, garlic, leek, shallot, chives. Pages 273-296 in: Diseases and Pests of Vegetable Crops in Canada. The Entomological Society of Canada (co-publisher), Ottawa, Ontario, Canada.

Lacy, M. L., and Pontius, G. A. 1983. Prediction of weather-mediated release of conidia of Botrytis squamosa from onion leaves in the field. Phytopathology 73:670-676.

Larentzaki, E., Shelton, A. M., Musser, F. R., Nault, B. A., and Plate, J. 2007. Overwintering locations and hosts for onion thrips (Thysanoptera: Thripidae) in the onion cropping ecosystem in New York. J. Econ. Entomol. 100: 1194-1200.

Leach, A., Reiners, S., Fuchs, M., and Nault, B. 2017. Evaluating integrated pest management tactics for onion thrips and pathogens they transmit to onion Agric. Ecosyst. Environ. 250:89-101.

Lewis, T. 1997. Flight and dispersal. Pages 175-196 in: Thrips as Crop Pests. T. Lewis, ed. CAB, Oxon, U.K.

McGhee, G. C., and Sundin, G. W. 2011. Evaluation of kasugamycin for fire blight management, effect on nontarget bacteria, and assessment of kasugamycin resistance potential in Erwinia amylovora. Phytopathology 101:192-204.

McKenzie, C. L., Cartwright, B., Miller, M. E., and Edelson, J. V. 1993. Injury to onions by Thrips tabaci (Thysanoptera: Thripidae) and its role in the development of purple blotch. Environ. Entomol. 22:1266-1277.

Mendiburu, F. 2016. Agricolae: Statistical Procedures for Agricultural Research. https://cran.r-project.org/web/packages/agricolae/index.html

Miller, M. E. 1983. Relationships between onion leaf age and susceptibility to Alternaria porri. Plant Dis. 67:284-286.

Molenaar, N. D. 1984. Genetics, thrips (Thrips tabaci L.) resistance and epicuticular wax characteristics of nonglossy and glossy onions (Allium cepa L.). Ph.D. dissertation, University of Wisconsin, Madison.

Nault, B. A., and Shelton, A. M. 2010. Impact of insecticide efficacy on developing action thresholds for pest management: A case study of onion thrips (Thysanoptera: Thripidae) on onion. J. Econ. Entomol. 103:1315-1326.

Nguyen, K. A., Förster, H., and Adaskaveg, J. E. 2018. Efficacy of copper and new bactericides for managing olive knot in California. Plant Dis. 102:892-898.

Parrella, M. P., and Lewis, T. 1997. Integrated pest management (IPM) in field crops. Pages 595-614 in: Thrips as Crop Pests. T. Lewis, ed. CAB International, New York.

Quartey, S. Q. 1982. Population dynamics of the onion thrips, Thrips tabaci Lind., on onions (Michigan). Ph.D. dissertation, Michigan State University, East Lansing.

R Core Team. 2015. R: A Language and Environment for Statistical Computing. R Foundation for Statistical Computing, Vienna, Austria.

Rueda, A., Badenes-Perez, F. R., and Shelton, A. M. 2007. Developing economic thresholds for onion thrips in Honduras. Crop Prot. 26:1099-1107.

Schroeder, B. K., Gitaitis, R. D., Dutta, B., and Schwartz, H. F. 2013. Bacterial diseases and their management. Pages 59-64 in: Onion Health Management and Production. H. F. Schwartz, ed. Colorado State University, Fort Collins, CO.

Sieburth, P. J., Schroeder, W. J., and Mayer, R. T. 1998. Effects of oil and oilsurfactant combinations on silverleaf whitefly nymphs (Homoptera: Aleyrodidae) on collards. Fla. Entomol. 81:446-450.

Smith, E. A., Ditommaso, A., Fuchs, M., Shelton, A. M., and Nault, B. A. 2011 Weed hosts for onion thrips (Thysanoptera: Thripidae) and their potential role in the epidemiology of Iris yellow spot virus in an onion ecosystem. Environ. Entomol. 40:194-203.

Smith, E. A., Fuchs, M., Shields, E. J., and Nault, B. A. 2015. Long-distance dispersal potential for onion thrips (Thysanoptera: Thripidae) and Iris yellow spot virus (Bunyaviridae: Tospovirus) in an onion ecosystem. Environ. Entomol. 44:921-930.

Stumpf, S., Gitaitis, R., Coolong, T., Riner, C., and Dutta, B. 2017. Interaction of onion cultivar and growth stages on incidence of Pantoea ananatis bulb infection. Plant Dis. 101:1616-1620.

Tho, K. E. 2018. Survey of bacterial foliage diseases in onions, their virulence, epidemiology and management. Ph.D. dissertation, Michigan State University, East Lansing, MI. ProQuest No. 10931395.

Tho, K. E., Wiriyajitsomboon, P., and Hausbeck, M. K. 2015. First report of Pantoea agglomerans causing onion leaf blight and bulb rot in Michigan. Plant Dis. 99:1034.

USDA-NASS. 2015. Quick Stats. United States Department of Agriculture-National Agricultural Statistics Service. https://quickstats.nass.usda.gov/results/79F89654 9E5D-300B-8AD2-08483CF4E7FC

Vahling-Armstrong, C., Dung, J. K., Humann, J. L., and Schroeder, B. K. 2016 Effects of postharvest onion curing parameters on bulb rot caused by Pantoea agglomerans, Pantoea ananatis and Pantoea allii in storage. Plant Pathol. 65:536-544.

Walcott, R. R., Gitaitis, R. D., Castro, A. C., Sanders, F. H., Jr., and Diaz-Perez, J. C. 2002. Natural infestation of onion seed by Pantoea ananatis, causal agent of center rot. Plant Dis. 86:106-111.

Wiriyajitsomboon, P., Tho, K. E., Byrne, J. M., and Hausbeck, M. K. 2014. Identifying and managing new and old onion diseases. In: Proc. Great Lakes Fruit, Veg. Farm Market EXPO. 